\title{
実験的脳アスペルギルス症に対するリン酸 ベタメサゾンナトリウムの影響
}

\author{
宮 治 誠* 藤原喜久夫* 西村 和子** \\ *干葉大学窝敗研究所鹰敗研究部 \\ 粐国立習志野病院皮膚科
}

\section{I. 緒言}

1969年西村 ${ }^{12}$ はマウスの脳を特異的に侵す Aspergillus fumigatus (以下 Asp. fum. と略す) の1分離秼につい て報告した. つついて藤原ら゙は25株のAsp. fum.を使 用し，これら菌株のマウス中枢神経系への侵襲性を比較 検討し，25株中 2 株がマウス中枢神経系を強く侵すこと

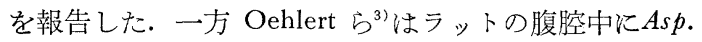
fum. を接種し，同時にヒアルロニダーゼを注射した場

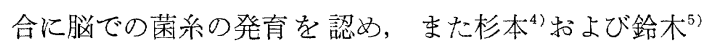
は Asp.fum. の胞子をマウスの尾静脈に接種後, 連日副 腎皮質ホルモンを投与した場合脳に菌系が発育している のを認めたと報告している.このように Asp.fum.の脳 への侵襲性に対して菌株に重きを沶く考方方と, 宿主の 状態に，より重きを执く考方方とが存在している.この 実験で著者らは Asp. fum.のマウスの脳への侵襲性の強 弱は菌株個有の性質によるものか，それとも宿主の状態 により，左右されるものであるのかを検討した。

\section{II. 実験材料と方法}

1）使用菌株：千葉大学腐敗研究所で保存されている Asp. fum. のらちマウスの脳を強く侵すことのないN I G E 株, A-F-7 株, A-F-8 株执よび K-11 株の 4 株を使 用した.これら 4 株のマウスに対する virulence，マウ スの脳に括ける菌系発育の程度および各臓器での病原性 に関しては以前に発表した2).

2）実験動物：体重 $22 \pm 1 \mathrm{~g}$ の dd 系の雄性のマウス を使用した.マウスは 1 群 2 匹とし，8群に分けられ， 各株につき 2 群が割り当てられた. この 2 群のらち 1 群

Makoto MIYAZI*, Kikuo FUJIWARA* and Kazuko NISHIMURA**: The Influence of Betamethasone disodium phosphate on Experimental Aspergillosis of the Brain in Mice. from the *Department of Sanitary Bacteriology, Institute of Food Microbiology, Chiba University. and **Department of Dermatology, Narashino National Hospital.
は対照として無処置のまま胞子を尾静脈に接種された が，他の 1 群は副腎皮質ホルモン様作用物質の連続投与 を受けつつ胞子を接種された。

3）副腎皮質ホルモン様作用物質並びにぞの投恃 法：リン酸ベタメサゾンナトリウム（商品名リンデロ ン，塩野義製薬製，以下「リ」と略す）を使用した。 1 群 2 匹としたマウスの 8 群のらち 4 群の各マウスに毎日

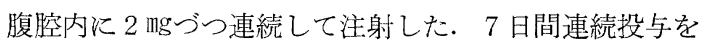
受けたマウスは8日目に胞子を尾静脈に接種された。な 扣胞子接種後もマウスは毎日連続して「リ」を注射され た。

4）菌液の調製および接種法：各菌株を $2 \%$ ブドウ糖 添加じやがいもェキス寒天培地室温で10日間培養し， 培盖された斜面寒天に Tween $80 を 0.01 \%$ 添加した $1 / 15 \mathrm{M}$ リン酸塩緩衝液（ $\mathrm{pH}$ 7.4）を適量注ぎ込み, ピペットで 軽く擋拌し, その浮遊液を他の滅菌試験管に移し, 上く 振盪して均一な胞子の浮遊液を作り, Thoma の血球計 算盤で胞子数を数兄， $0.2 \mathrm{ml}$ 中 $5 \times 10^{6}$ 個の胞子を含む よう菌液を調製した，この調製された各株の菌液は（菌 液の調製を開始してから 1 時間後に）1株につさ2群 あてに（このうち1群は「リ」が連続投与されている） マウスの尾静脈に $0.2 \mathrm{ml}$ あて接種された.

5）肉眼的並びそ組織学的観察法 : 胞子を接種された マゥスは72時間後に屠殺され，肉眼的並びに組織学的 検相に供された。なお組織の固定にはホルマリンを使用 乙, 染色は H \& E 染色, Luxol fast blue とPA Sの 重染色扮よび Cresylechtviolet 染色を用いた。

6）脳汹抢ける菌系発育並びそ細胞浸潤の範团の測定 法：前に報告 ${ }^{6)}$ したようにマウスの頭蓋骨を開き, 破損 せぬより注意しながら脳を取り出し，ホルマリン固定後 嗅脳より外耳孔上縁を結ぶ線で水平飞切断し（標本 A), 更に切り離された上部の組織より大脳と小脳の部位の 2 
Table 1 Gross anatomical findings

\begin{tabular}{|c|c|c|c|c|c|c|c|c|}
\hline \multirow{2}{*}{ organs } & \multicolumn{2}{|c|}{ brain } & \multicolumn{2}{|c|}{ kidneys } & \multicolumn{2}{|c|}{ spleen } & \multicolumn{2}{|c|}{ other organs } \\
\hline & M.D.P. & control & M.D.P. & control & M.D.P. & control & M.D.P. & control \\
\hline NIGE & $\begin{array}{c}\text { hemorrhage } \\
( \pm)\end{array}$ & $\begin{array}{c}\text { hemorrhage } \\
( \pm)\end{array}$ & $\begin{array}{c}\text { microabscess } \\
(+++)\end{array}$ & $\begin{array}{c}\text { microabscess } \\
(+)\end{array}$ & $\begin{array}{l}\text { atrophy } \\
(+++)\end{array}$ & $\begin{array}{c}\text { atrophy } \\
(-)\end{array}$ & normal & normal \\
\hline$A-F-7$ & " & " & $\begin{array}{c}\text { microabscess } \\
(+++)\end{array}$ & $\begin{array}{c}\text { microabscess } \\
(++)\end{array}$ & " & " & " & " \\
\hline$A-F-8$ & " & " & $\begin{array}{c}\text { microabscess } \\
(+++)\end{array}$ & $\begin{array}{c}\text { microabscess } \\
(++)\end{array}$ & " & "I & "I & " \\
\hline $\mathrm{K}-11$ & " & " & $\begin{array}{c}\text { microabscess } \\
(+)\end{array}$ & $\begin{array}{c}\text { microabscess } \\
(+)\end{array}$ & " & " & " & " \\
\hline
\end{tabular}

cf : i) $\quad \underset{\text { none }}{(-)} \rightarrow \begin{gathered}(+++) \\ \text { conspicuous }\end{gathered}$

ii) M.D.P.: betamethasone disodium phosphate

(72 hours after injection)

枚の綎断面の組織標本作製した（標本 B，C）。次に標 本 $\mathrm{A}, \mathrm{B}, \mathrm{C}$ の面積を計測して 3 者の和を標本の総面積 と乙て算出し, 同時に標本 $\mathrm{A}, \mathrm{B}, \mathrm{C}$ 中での菌糸が発育 している面積および細胞が浸潤している面積をミクロメ ーターを用いて計測し，この総和を標本総面積で割り 100倍して\%で表わした.な拉 1 群 2 匹の割で実験を行 なつている故, 数值は平均して表わしてある.

\section{III. 結 果}

1）剖検所見：剖検所見は表 1 亿示した.「り」投与 群，対照群共に脳任異常を認めなからた。 しかし腎にお ける膿瘍の形成は「リ」投与群に执いてょり著しい傾向 がうかがわれた、また「り」投与群に扔いて脾の強い萎 縮が認められた。

2）脳の組織学的所見：全例飞括いて多少の差はある が以下に述べる変化が認められた．即ち大脳に括いても 灰白質白質を問わず多形核白血球を主とした小規模の細 胞浸潤巣が散在性に認められ（写真 1 ），その中心に菌系 が認められる場合と少なくとも切片上では細胞浸潤のみ で菌系は全く認められない場合が存在した。これら病巣 の部位並びに程度によつて出血, 壊死, 神経細胞の変性 (写真 2) 拈よび脱䯣現象（写真 3 ）が附随して起こつ ているのが散見されたが，「リ」投与群と対照群との間 に特に差は認めら机なからた。

3）脳に括ける菌系発育扣よび 細胞浸潤の範国の比 率：標本中に拈汗る細胞浸潤括よび菌采の発育している 面積が標本全体の面積の何\%にあたるかを計算した結果 を表 2 に示した。 即ち「リ」を投与された群が対照群と 比較して脳汇括ける菌系の発育が増大しているとは認め られなかつた．この結果はマウスの脳で発育しにくい株
Table 2 The growth of hyphae and cell infiltration

\begin{tabular}{l|c|c|c|c}
\hline \multirow{2}{*}{ groups } & \multicolumn{4}{|c}{ strains } \\
\cline { 2 - 5 } & NIGE & A-F-7 & A-F-8 & K-11 \\
\hline $\begin{array}{l}\text { betamethasone } \\
\text { disodium } \\
\text { phosphate }\end{array}$ & $1.92 \%$ & $1.69 \%$ & $0.76 \%$ & $0.13 \%$ \\
\hline control & $2.91 \%$ & $0.86 \%$ & $0.25 \%$ & $0.38 \%$ \\
\hline
\end{tabular}

は，たと兄「り」を投与し宿主の抵抗力を減弱させたと しても脳での発育は注とんど影響を受けないことを示す と思われる.

4）との他の臟器の組織学的所見 : 腎では「リ」投与 群において大小の菌系発育巣を中心とした単核球, 好中 球, 核片よりなる細胞浸潤巣が多数認められ，それらの 病巣周辺和よび末梢の細尿管上皮には変性が認められた (写真 4). N I G E株, A-F-7 株の胞子を接種されたマ ウスの 2 匹中各 1 匹に，K-11 株は 2 匹中 2 匹飞真菌性 腎孟炎が認められ，菌系の発育が見られた。対照群でも 「リ」投与群に比べて菌系を中心とした膿瘍形成の数は 少ないがかなり認められた。 また細尿管上皮の変性も 「リ」投与群に比べて軽度であつた. な抋小規模の真菌 性腎盂炎が対照群に揖いても K-11 株の 2 匹中 1 匹だけ に認められた。

心では「リ」投与群は対照群に比べて小さい細胞浸潤 巣（中心に菌系発育のある場合もない場合もあつた）は 多少増加しているが影著な差は認められなかつた。 また 心朌線維の変性は「リ」投与群に执いてやや著しからた (写真 5 ).

肝では両群共に小さい細胞浸潤栄が散在し顕著な差は 


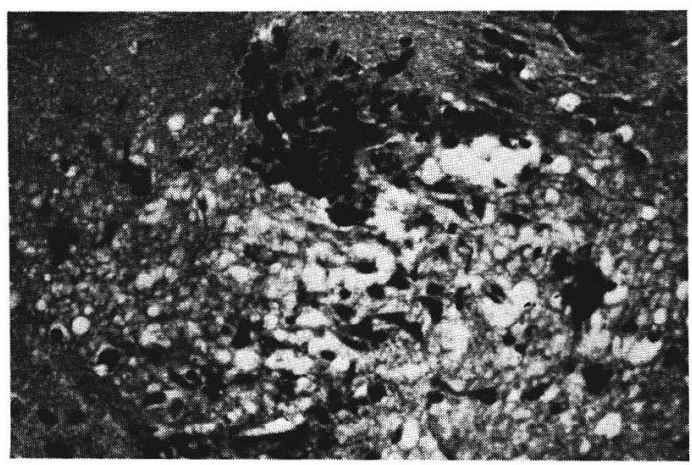

写真 1. Luxol fast blue, PAS重染色 $\times 200$ A-F-8 株，「リ」投与群，侧頭葉 菌系を中心に好中球の浸潤があり，その下方に軟化 壊死と神経細胞の変性が見られる。

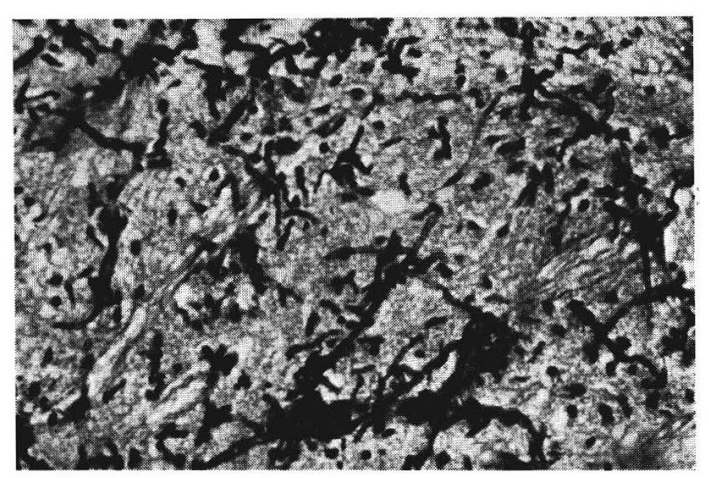

写真 3. Luxol fast blue, PAS 重染色 $\times 200$ A-F-7 株, 対照群, 線状体

樹枝状の菌系発育。一部にグリヤと好中球よりなる ごく㪕度の細胞浸潤がある. 斜走している(上方で は横断されている) 神経線維に脱䯣がみられる。

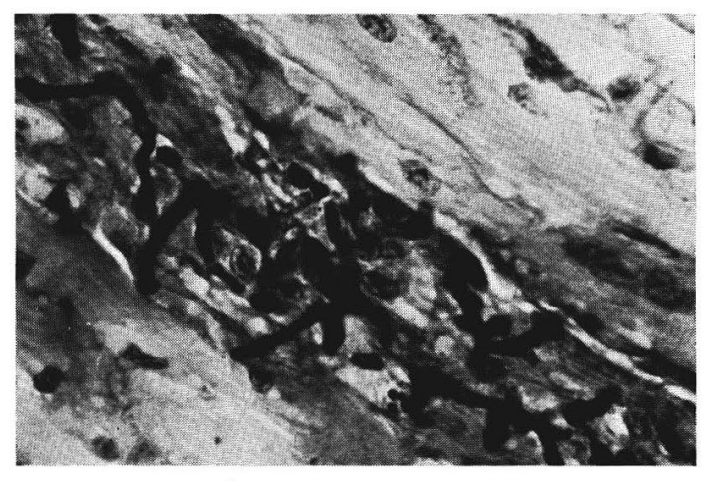

写真 5. P A S 染色 $\times 400$

A-F-7 株，「リ」投与群，心

心筋線維の間にみられた菌䒺。まわりに大型の峃核 球が少数ある。

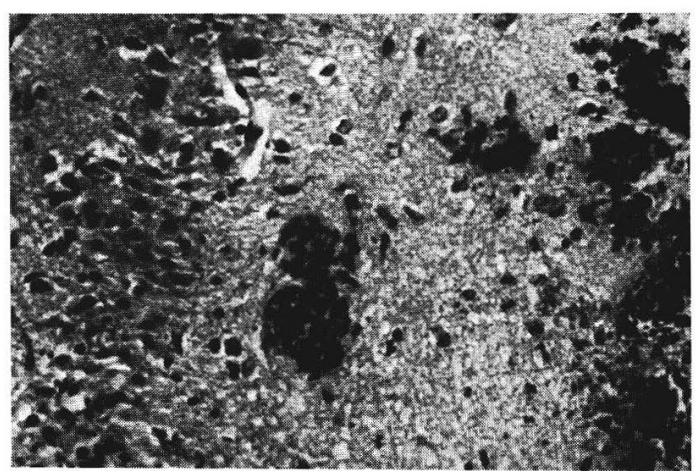

写真 2. Luxol fast blue, PAS 重染色 X 200 A-F-8 株, 対照群，ヒポ刃ンプス

好中球と核片よりなる小さい細胞浸潤巣が散在, 右 下方には出血, 左方にはヒポカンプスの神経細胞に 変性が見られる。

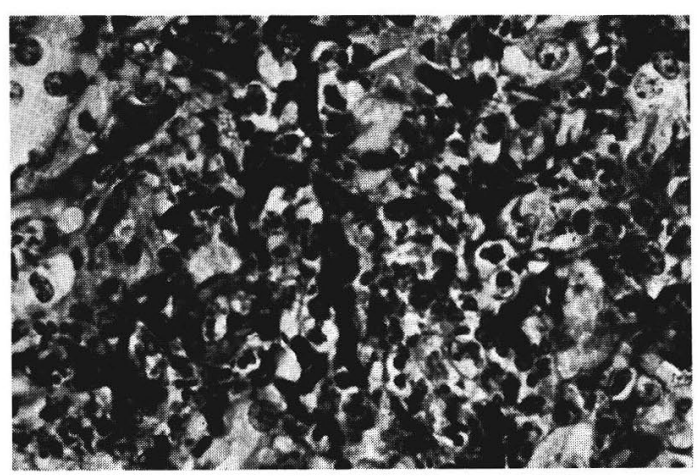

写真 4.PA S 染色 $\times 400$

$\mathrm{K}-11$ 株, 「リ」投与群，腎

菌系を中心に好中球, 細胞の破片, 核片がみられる。 辺縁の細尿管上皮の変性, 消失が著しい。

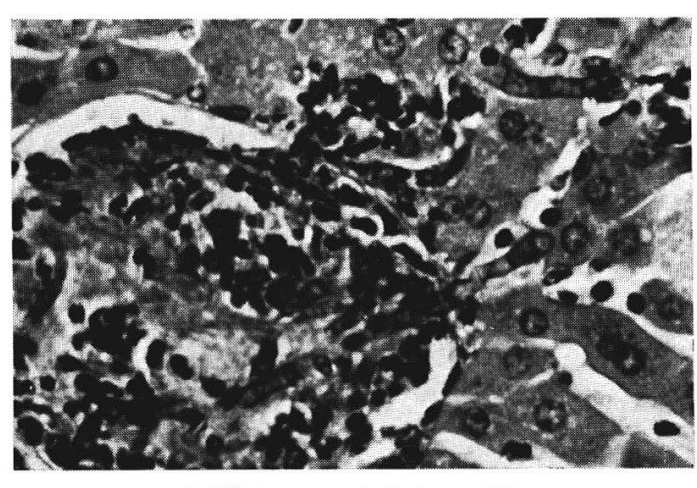

写真 6. P A S 染色 $\times 400$

$\mathrm{K}-11$ 株, 「リ」投与群, 旰

中心静脈壁を貫ぬいて菌糸が発育している. 


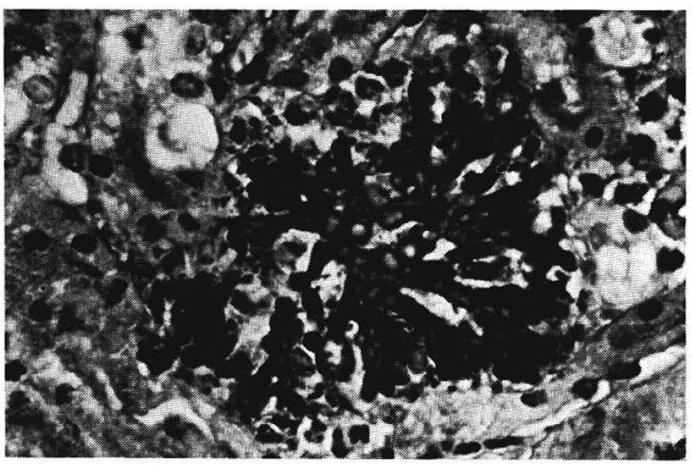

写真 7.P A S 染色 $\times 400$

A-F-7 株, 「リ」投与群, 肺 太い菌系が樹枝状に発育している。（辺緣の肺胞上 皮の増殖が著しい）

認められなかつた. しかし，A-F-7 株， K-11 株におい て「リ」投与群の各 1 匹に中心静脈, 肝静脈を中心とし た菌系発育巣が散見された (写真 6 ).

脾では「リ」投与群は著しいリンパ濾胞の萎縮を示 し，発芽管を伸ばしている胞子が多数脾細胞に喰食され ているのが認められたが，両群共菌糸発育巣はきわめて 少なく，から小規模で両群の間に差を認めることは出来 なかつた。

肺では両群共部分的にうつ血あるいは軽度ないし中等 度の間質性肺炎の像を示した. A-F-7 株の「リ」投与群 の 2 匹に菌系発育（写真 7 ）を中心とした小膿瘍が散見 されたが他の 3 株では両群とも菌糸は認められなかつ た.

以上総括してみると，「リ」投与群は対照群に比べて 腎においては感染の促進が明らかに認められた. しかし ながら, 他の臓器では菌株によつては菌糸発育の出現あ るいは増加, 実質細胞の变性の増加が認められたが 4 株 に共通して感染の促進が起こつているわけではなく，両 群の間にはつきりした差を認めることは出来なからた。

\section{IV. 考按}

動物を使用した Asp.fum.の感染実験は現在なでかな り報告されている。しかし脳への侵襲性に焦点をあてた 研究は僅かに散見されるにすぎない. 1880年 Grawitz ${ }^{7)}$ は Aspergillus をウサギと犬の䫋動脈中に接種し脳に病 巣を作つたことを報告している．1954年 $\mathrm{Eger}^{8)}$ は人の 脳アスペルギルス症より分離した Asp. fum.をラットの 腹腔内に接種し，脳実質に菌系が豊富に発育しているの を観察した. 1969年西村 ${ }^{1)}$ はウスの脳を特異的に侵
す Asp.fum. の 1 分離株につき報告し，同年藤原ら ${ }^{2)}$ は 患者, 空中および土㙋中より分離された25株のAsp. fum. を使用し，これら菌株のマウス中枢神経系への侵襲度を 定量的に計測し，25株中 2 株がマウスの中枢神経系を強 く侵すことを報告した. 1971年西村扎よび宮治6)はAsp， fum. のマウスの脳における発育を経時的, 定量的に追 求し, また Laovoravit ${ }^{9)}$ はウサギを使用して Asp. fum. の脳に対する感染を病理学的に詳しく記載した.ここ でどの様な株がマウスの脳を強く侵す株であるかという 著者らの基準を述べてみたい，著者らは組織学的所見よ りも，肉眼的所見に重きを扣いている. 即ち， $5 \times 10^{6}$ 個の胞子をマウスの尾静脈に注入した場合少なくとも 4 日以内にマウスの脳は著しく腫脹し,その為矢状縫合は $1 \sim 2 \mathrm{~mm}$ の巾に離解し, 大脳縦裂および小脳横裂は密着 しており，同時に大脳半球表面近くに大小の出血巣が透 見される場合である.このような場合は菌系が脳内で縱 横に発育しているのが観察され, 組織がどの方向に切ら れて作製されても豊富に発育した菌系を認めることが出 来るのである．逆にいえば顕微鏡的に観察してやつと見 出されるような菌系の発育や微小な膿瘍 (中心に菌糸が 認められる場合と認められない場合がある）や，またた と光比較的大きい膿瘍を作りその中でやや太めの菌系が 見出されるような場合でも，上記の肉眼的所見がないか ぎり脳を強く侵す株とは認めていない，この実験で著者 らが使用した 4 株は脸を強く侵す株ではない. しかしこ のような株でもなんらかの方法で宿主の抵抗力を減退さ せた場合脳への侵襲性が増大するか否かを検討する為, この実験を行なつた.人間に拈いては消耗性疾患, 抗生 物質, 副腎皮質ホルモン剂等の投与を受けている患者に 真菌感染が増加しているのは日常よく見うけられ，また 副腎皮質ホルモン，A C T H剂，抗腫瘍剂を投与された 動物, レントゲン照射された動物はAsp. fum.の感染が 促進されたといら報告もある(1)510 20). 特に脳に対して も Oehlert ら3'はラットの腹腔内に Asp. fum. を接種 し同時にヒアルロニダーゼを投与すると脳に菌糸の発育 が起こつてきたことを報告し，また杉本 ${ }^{4)}$ および鈴木 ${ }^{5)}$ はAsp. fum. の胞子をマウスの尾静脈に接種後連日コー チゾンを投与した場合に脳に菌系の発育を認めたと述 ベている.しかし彼らの実験ではなるほど脳の組織内 に菌糸を認めたかもしれないが肉眼的に見て上記のよう な強い变化は観察されていない. このように Asp. fum. の脳への侵襲珄に対して菌株に重きを和く著者らの考兄 方と, 宿主の状態により重きを扣く考え方とが存在す 
る、しかし，著者らの実験でみるかぎりでは「リ」を投 与された群と対照群との間に脳への侵襲性に差を認める ことは出来なからた。しかし，興味あることは，腎炕お いては「リ」投与群の方が感染は著しく促進されていた ことである。したがつて，菌株が本来感染を起こし易い 蔵器では宿主の抵抗力が減退した場合その蔵器での感染 は促進されるが，その株にとつてあまり感染を起こしに くい臟器では宿主の抵抗力が弱められた場合でも感染を 飛躍的に促進することは難しいように思われた。

\section{V. 結 論}

Asp. fum. の 4 株を使用しマウスの脳への侵襲性飞対 する副腎皮質ホルモン様作用物質（リン酸ベタメサゾン ナトリウム) の影響を調べた結果, 本物質投与群は対照 群と比較して脳での感染の促進を認めることは出来なか つた.

\section{文献}

1) 西村和子：真菌之真菌症，10，170，1969.

2）藤原喜久夫, 宮治 誠, 西村和子, 倉田浩: 干 葉大学萑敗研究所報告, 22, 33, 1969.

3) Oehlert, V.W. und Düffel, F.: Zbl. allg. Path., 98, 41, 1958.

4) 杉本 裕：日新医学，46，675，1959.

5）鈴木文直：真菌之直菌症， 9, 280, 1968.

6) 西村和子, 宮治誠：真菌と真菌症, 12, 24, 1971.

7) Grawitz, P.: Arch. Path. Anat. Physiol.
Klin. Med., 81, 355, 1880.

8) Eger, W. und Kührt, P.: Dtsch. Ztschr. Nervenh., 171, 370, 1954.

9) Laovoravit, M.: Japan. J. Med. Mycol., 11, $15,1970$.

10) Mankowski, Z.T. and Littleton, B.J.: Antib. \& Chemo., 4, 253, 1954.

11) Zimmerman, L.E.: Amer. J. Clin. Path., 25, 46, 1955.

12) Keye, J.D. and Magee, W.E.: Amer. J. Clin. Path., 26, 1235, 1956.

13) Sidransky, H. and Friedman, L.: Amer. J. Path., 35, 169, 1959.

14) Louria, D.B. and Browne, H.G. : Ann. N.Y. Acad. Sci., 89, 39, 1960.

15) 千葉直彦：真菌之真菌症，7，82，1966.

16) Epstein, S.M., Verney, E., Miale, T.D. and Sidransky, H.: Amer. J. Path., 51, 769, 1967.

17) Merkow, L., Pardo, M., Epstein, S.M., Verney, E. and Sidransky, H.: Science, 160, 79, 1968.

18) Sandhu, D.K., Sandhu, R.S., Damodaran, V.N. and Randhawa, H.S.: Indian J. Chest Dis., 11, 115, 1969.

19）後藤靖彦：直菌と真菌症，11，7，1970.

20) Sandhu, D.K., Sandhu, R.S., Damodaran, V.N. and Randhawa, H.S.: Sabouraudia, 8, 32, 1970 .

（昭和 47 年 3 月 11 日受付）

\begin{abstract}
The influence of betamethasone disodium phosphate was studied on cerebral infections of mice with 4 strains of Aspergillus fumigatus. Experimentally, the strains invade severely the kidneys of mouse but less the tissues of the brain. Male mice of dd line weighing $22 \pm 1 \mathrm{~g}$ were used for the animal experiment. They were divided into 8 groups of 2 mice each. Two groups per one strain were employed and one group of them was received continuous 10 days' administration of betamethasone disodium phosphate, $2 \mathrm{mg} /$ day, intraperitoneally.

On the other hand, spore suspensions were prepared in $1 / 15 \mathrm{M}$ phosphate buffer ( $\mathrm{pH} 7.4$, supplemented with $0.01 \%$ tween 80 ) from 10 days cultures of the test strains on potato dextrose agar at room temperature. The number of spores was determined by the direct count with Thoma's hemocytometer chamber.

After 7 days' administration of the drug, each mouse was injected intravenously $5 \times 10^{6}$ spores of the strain suspended in $0.2 \mathrm{ml}$ phosphate buffer solution. After 72 hours of injection, mice were sacrified and examined grossly and microscopically.

The extent of the growth of hyphae and cell infiltration of the brain was determined by the following method; after fixation with $10 \%$ formalin solution, the brain was cut from three directions (section A, B
\end{abstract}


and C).

Section A was made by cutting horizontally along with the straight line that connects the olfactory brain and the upper part of the external ear hole. The section B was made from the cerebrum by cutting vertically and the section $\mathrm{C}$ was made from the cerebellum. Each section was stained with hematoxylineosin, periodic acid Schiff stain of Hotchkiss-McManus, luxol fast blue and cresylechtviolet.

By using micrometer, the areas of section $\mathrm{A}, \mathrm{B}$ and $\mathrm{C}$ were measured (this was termed total area). The sum of areas showing the growth of hyphae and cell infiltration on the three sections was also measured. The ratio of that to the total area was calculated with the average data from 2 mice.

Grossly, no brain was swollen although a few hemorrhagic areas were found on the surface of the tissue. Microscopically, in all tissues of the brain small sporadic lesions that were composed of aggregates of leucocyte with a few hyphae were observed. Besides, necrotic foci, hemorrhagic areas, degeneration of nervous cells and demyelinization were observed. The extent of the growth of hyphae and cell infiltration in the brain was as follows; in the groups injected betamethasone disodium phosphate, the areas affected by the strain NIGE was $1.92 \%$, the strain A-F-7 1.69\%, the strain A-F-8 $0.76 \%$ and the strain K-11 $0.13 \%$, while, in the groups without administration, the strain NIGE $2.91 \%$, the strain A-F-7 $0.86 \%$, the strain A-F-8 $0.25 \%$ and the strain K-11 $0.38 \%$.

From the result, it seems to be considered that there is no definite influence of betamethasone disodium phosphate on the cerebral infection. However, mycotic lesions were established severer in the kidneys of mice injected betamethasone disodium phosphate than that not administered. 


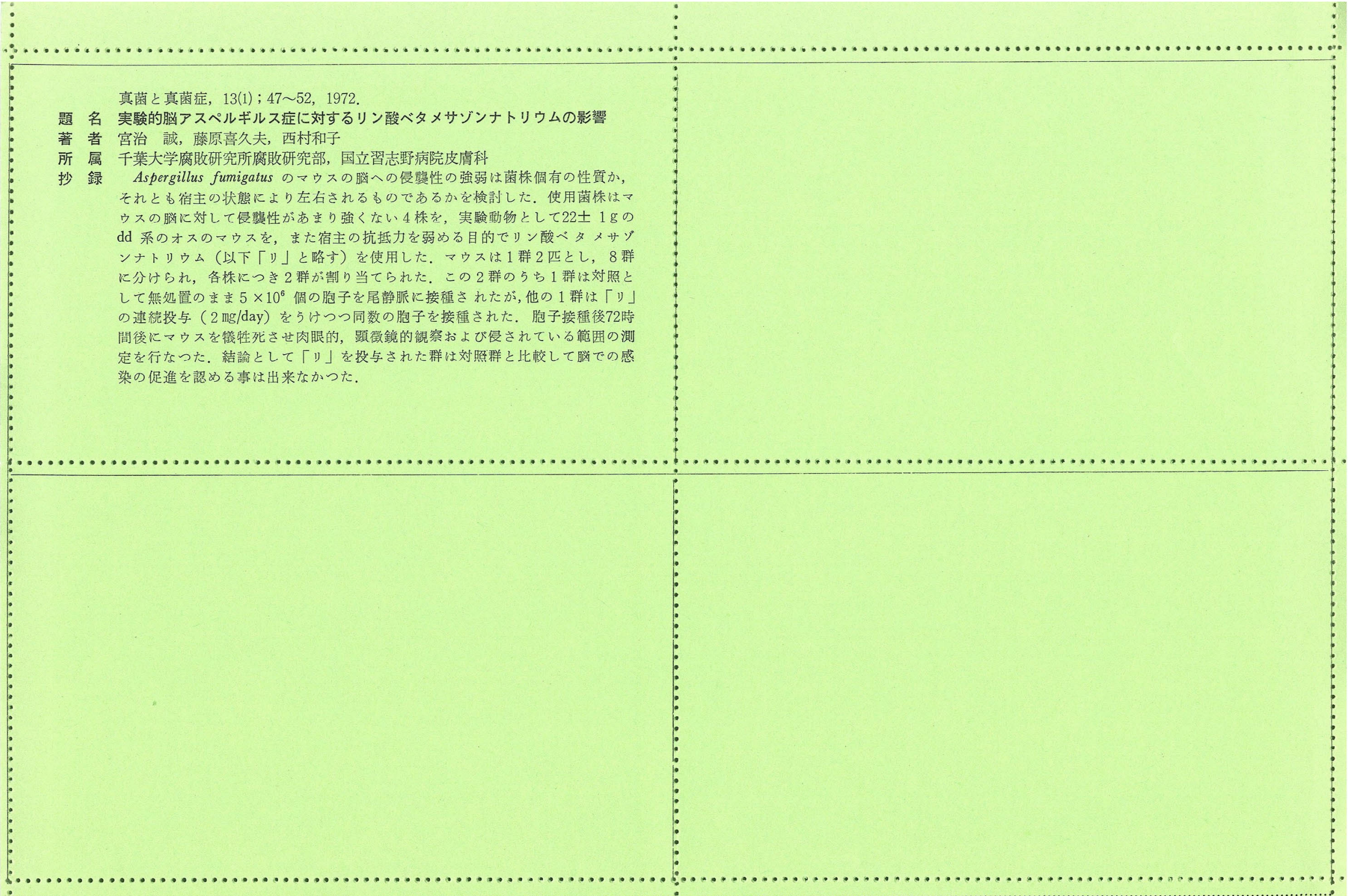

真菌と真菌症，13(1)；47〜52，1972

題 名 実験的脳アスペルギルス症に対するリン酸ベタメサゾンナトリウムの影響

者 宮治 誠, 藤原喜久夫，西村和子

属 千葉大学腐敗研究所腐敗研究部, 国立習志野病院皮盧科

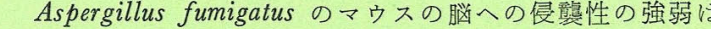

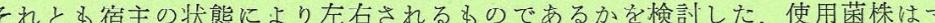

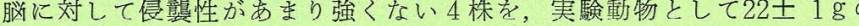
定を行なつた，結諭として「り」を投与された群は対照群と比較して脳での感 染の促進を認める事は出来なかつた。 